\title{
POTICANJE SOCIJALNE INTERAKCIJE PUTEM SOCIJALNIH PRIČA U DJEČAKA S POREMEĆAJEM IZ SPEKTRA AUTIZMA
}

\author{
MAGDALENA JANČEC ${ }^{1}$, SANJA ŠIMLEŠA ${ }^{2}$, JASMINA FREY ŠKRINJAR ${ }^{2}$ \\ ${ }^{1}$ Centar za autizam, Ljevakovićeva 30a, Zagreb, ${ }^{2}$ Edukacijsko-rehabilitacijski fakultet Sveučilišta u Zagrebu, \\ kontakt:s.simlesa@gmail.com
}

Primljeno: 18.1.2016.

Prethodno priopćenje

Prihvaćeno: 23.3 .2016 .

UDK: $616.89-053.2$

Sažetak: Socijalne priče su kratke priče, pisane i prilagođene djeci s poremećajem iz spektra autizma čiji je cilj poboljšanje socijalnih i/ili komunikacijskih vještina djece, podučavanjem primjerenih oblika ponašanja u socijalnim situacijama. Socijalne priče često se koriste u intervencijskim programima za djecu s poremećajem iz spektra autizma, najčešće s ciljem smanjenja nepoželjnih ponašanja te u podučavanju socijalnih vještina. Suvremena istraživanja utjecaja socijalnih priča na poticanje socijalnih vještina djece s poremećajem iz spektra autizma još uvijek nisu potvrdila njihovu učinkovitost, a ovaj rad, čiji je cilj ispitivanje utjecaja socijalnih priča putem video modeliranja na vještine socijalne interakcije dječaka s visokofunkcionirajućim autizmom, prvo je istraživanje učinkovitosti socijalnih priča u Republici Hrvatskoj. U istraživanju je sudjelovao dječak $(5,2)$ s dijagnozom visokofunkcionirajućeg autizma. U podučavanju vještina socijalne interakcije korištene su socijalne priče putem video modeliranja. Kako bi se ostvario cilj rada, provedeno je istraživanje u obliku studije slučaja, sastavljeno od kvantitativnog i kvalitativnog djela. Kvantitativni dio istraživanja donosi rezultate mjerenja učestalosti iniciranih socijalnih interakcija u dječaka, kroz dvije vremenske točke te rezultate mjerenja učestalosti odgovorljivosti na interakciju iniciranu od strane vršnjaka, kroz dvije vremenske točke. U kvalitativnom dijelu istraživanja, prikazani su rezultati procjene kvalitete iniciranja interakcije u dječaka, kroz dvije vremenske točke, te kvalitete odgovorljivosti na interakciju iniciranu od strane vršnjaka, kroz dvije vremenske točke. Rezultati potvrđuju hipoteze istraživanja; potvrđuju učinkovitost socijalnih priča u podučavanju socijalnih vještina sudionika istraživanja, ukazuju na potrebu za implementacijom socijalnih priča putem video modeliranja u daljnje ciljeve za sudionika istraživanja kao i na potrebu za daljnim istraživanjima učinkovitosti socijalnih priča putem video modeliranja u populaciji djece s visokofunkcionirajućim autizmom.

Ključne riječi: poremećaj iz spektra autizma, visokofunkcionirajući autizam, socijalne interakcije, socijalne priče, video modeliranje.

\section{UVOD}

\section{Poremećaj iz spektra autizma}

Peto izdanje Dijagnostičkog i statističkog priručnika duševnih poremećaja (DSM - V) donijelo je određene novine u definiranju poremećaja iz spektra autizma: uvođenje jedinstvenog termina "poremećaj iz spektra autizma" za sve potkategorije koje su postojale u prethodnom izdanju, podjelu poremećaja prema stupnju razine teškoća (gdje je stupnju 1 pridružena minimalna ili nikakva razina podrške, a stupnju 3 maksimalna moguća razina podrške), promjene u dijagnostičkim kriterijima te uvođenje nove dijagnostičke kategorije (poremećaj socijalne komunikacije) (American Psychiatric Association, 2013). Poremećaj iz spektra autizma je neurorazvoj- ni poremećaj kojeg karakteriziraju teškoće u socijalnoj komunikaciji, odnosno interakciji te ograničeni i ponavljajući obrasci ponašanja, interesa i aktivnosti.

\section{Visokofunkcionirajući autizam}

Prema DSM-V, visokofunkcionirajući autizam pripada skupini poremećaja iz spektra autizma stupnja 1, a karakteriziraju ga, uz osnovne značajke poremećaja iz spektra autizma, uredne intelektualne sposobnosti. U djece s visokofunkcionirajućim autizmom prisutno je kašnjenje u ranoj fazi jezičnog razvoja (0-3) (American Psychiatric Association, 2013).

Navedena skupina djece pokazuje sužen raspon vještina socijalne komunikacije, što se očituje kao 
teškoće u: (1) recipročnoj socijalnoj komunikaciji, (2) zahtijevanju informacija ili predmeta od odraslih osoba/vršnjaka, (3) odgovaranju na interakciju iniciranu od strane odraslih osoba/vršnjaka te (4) sudjelovanju u jednostavnim igrama i drugim aktivnostima (Sansosti i Powell-Smith, 2008).

Jezično-govorni razvoj djece s visokofunkcionirajućim autizmom karakteriziraju teškoće u pragmatici i prozodiji (Rubin, Lennon, 2004). Kod djece s visokofunkcionirajućim autizmom istaknuta je sklonost doslovnom tumačenju iskaza, koja vodi teškoćama u razumijevanju idioma, humora, metafora, ironije, laži, šala, pretvaranja i sarkazama koji su sveprisutni u svakodnevnoj socijalnoj komunikaciji (Moldin i Rubenstein, 2006). Teškoće su izražene u socijalnom kontekstu, uporabi jezika te funkcionalnoj komunikaciji (Tager-Flusberg, 2007), razumijevanju socijalnih rutina te interpretaciji govora tijela (mimika, geste, razumijevanje i izražavanje emocija) (Hobson i Meyer, 2005).

Djeca s visokofunkcionirajućim autizmom, kao i sva druga djeca (i odrasli) komuniciraju za različite komunikacijske funkcije koje se mogu svrstati u imperativne i deklarativne (Bates i sur., 1975; prema Ljubešić i Cepanec, 2012). Dok je cilj imperativnih funkcija izražavanje potrebe, $u$ kojoj komunikacijski partner služi isključivo kao "instrument" za dostizanje određenog "fizičkog" cilja, cilj deklarativnih funkcija je dijeljenje iskustva ili informacija s komunikacijskim partnerom. Omjer iniciranja komunikacije za imperativne i deklarativne funkcije važan je pokazatelj razvoja socijalne komunikacije. Tipičan komunikacijski obrazac karakterizira premoć deklarativnih nad imperativnim funkcijama, a prevladavanje imperativnih funkcija (ponekad bez postojanja deklarativnih) ukazuje na atipični komunikacijski obrazac (Ljubešić i Cepanec, 2012). Atipičan komunikacijski obrazac odlika je većine djece s poremećajem iz spektra autizma.

Komunikacijska sredstva su svi naši "alati” za prenošenje poruka, tj. načini na koje poruku činimo fizičkom (bilo u obliku akustičkog, vidnog ili taktilnog podražaja) (Ljubešić i Cepanec, 2012).

U skladu s navedenim, procjena komunikacije temelji se na procjeni:

1. Načina, sustava i razine komunikacije (Kako?);
2. Konteksta komunikacije (Gdje? Kada?);

3. Sadržaja (funkcije) komunikacije (Zašto?).

Procjena komunikacije daje podatke o tome: (1) Kako dijete samostalno komunicira (način - sredstvo)? (2) Kada i gdje ima potrebu za komunikacijom (kontekst)? te (3) O čemu želi komunicirati (svrha i sadržaj)?.

Važna karakteristika djece s visokofunkcionirajućim autizmom postojanje je specifičnih interesa i neobičnih ponašanja, koja se negativno odražavaju na područje socijalnih interakcija jer povećavaju socijalnu izolaciju. Termin specifičnih interesa podrazumijeva interese i aktivnosti neobično jakog intenziteta i trajanja (South i sur., 2007), koji mogu ugrožavati odnose s vršnjacima ukoliko se ne pretvore $\mathrm{u}$ funkcionalne hobije ili adaptivne vještine. Neobična ponašanja obično su vezana uz uspostavljanje i održavanje rutina (Atwood, 2010).

\section{Video modeliranje}

Kako bi osobe s poremećajem iz spektra autizma u edukativnom procesu bile produktivne i responzivne, neophodno je osigurati okruženje koje je jasno strukturirano, a korištene metode prilagođene podučavanju osoba s autizmom kao prirodnih biheviorista i vizualno orijentiranih učenika (Nikopoulos i Keenan, 2006).

Posljednje desetljeće obilježeno je intervencijama temeljenima na tehnologiji, a brojna istraživanja dokazuju njihovu učinkovitost u tretmanu osoba s poremećajem iz spektra autizma (Grynszpan i sur., 2013). Jedna od znanstveno utemeljenih metoda intervencije iz kategorije računalnih tehnologija je i video modeliranje (Prelock i McCauley, 2012). Tehnika video modeliranja način je podučavanja opažanjem, u kojem osoba promatranjem ponašanja druge osobe putem video prikaza, uči ciljano (primjereno ponašanje) imitacijom modela, $u$ određenim okolinskim uvjetima (Bellini i Akullion, 2007). U ovom istraživanju koristi se integrirana $u$ bihevioralni pristup podučavanja, kao potkategorija intervencija temeljenih na tehnologiji.

Istraživanja utjecaja video modeliranja na vještine socijalne interakcije u podučavanju djece s poremećajem iz spektra autizma pokazuju pozitivnu međusobnu povezanost navedenih konstrukata. Potvrđena je pozitivna povezanost video modelira- 
nja i poboljšanja u vještinama teorije uma, izvršnim funkcijama te jezičnoj pragmatici (Dawson i sur., 2004), združenoj pažnji (Murray i sur., 2008) i ponašanjima koja iz njih proizlaze poput dijeljenja, recipročnih socijalnih interakcija (Gutstein i Whitney, 2002), empatije te vokalne i motoričke imitacije (LeBlanc i Coates, 2003).

\section{Socijalne priče}

Socijalne priče su kratke priče pisane i prilagođene djeci s poremećajem iz spektra autizma, čiji je cilj poboljšanje socijalnih vještina kroz podučavanje primjerenih oblika ponašanja u socijalnim situacijama (Gray, 1998), a pripadaju skupini bihevioralnih intervencija te pritom koriste kombinaciju vizualne i verbalne podrške (O'Hara, 2010).

Socijalne priče opisuju konkretnu situaciju tumačeći relevantne društvene signale, perspektivu drugih, a često predlažu i odgovarajući odgovor na ponašanje u određenoj situaciji (Reynhout i Carter, 2007). Na taj način pomažu prevladati teškoće u teoriji uma, odnosno, teškoće u razumijevanju mišljenja, želja i namjera drugih, karakteristične za djecu s visokofunkcionirajućim autizmom (BaronCohen, 2010).

Svaka socijalna priča ima jasno definiranu strukturu: daje odgovore na pitanja o osobi (Tko?), predmetu ili događaju (Što?), mjestu (Gdje?) te vanjskim i unutarnjim motivima za ponašanje (Zašto?) u određenim situacijama, objašnjava stavove i emocije drugih u konkretnoj situaciji, opisuje ono što se od djeteta u konkretnoj situaciji očekuje da učini ili kaže. Također, djetetu pruža objašnjenje socijalne prihvatljivosti podučavanog ponašanja.

Socijalne priče prvotno su bile namjenjene podučavanju djece s visokofunkcionirajućim autizmom jer je polazište i preduvjet u kreiranju socijalnih priča bila što veća očuvanost jezično-govornih sposobnosti, koje će omogućiti usvajanje ciljanih socijalnih ponašanja (Gray, 1994). Danas se socijalne priče koriste i kod djece s većim stupnjem teškoća, ali u modificiranom obliku i uz prevladavanje vizualne podrške (Gray, 1994).

Unatoč brojnim istraživanjima, učinkovitost socijalnih priča još uvijek nije znanstveno dokazana. Socijalne priče načelno se koriste uz druge intervencijske postupke poput pozitivnog pojača- nja ili modeliranja te je stoga teško identificirati specifičnu komponentu intervencijskog programa koja je uvjetovala njegovu učinkovitost (Reynhout i Carter, 2006; Kokina, Kern, 2010).

Istraživanja učinkovitosti socijalnih priča kod djece s poremećajem iz spektra autizma, koja pokazuju pozitivnu povezanost između podučavanja putem socijalnih priča i usvajanja novih vještina, uobičajeno polaze od ispitivanja jezičnog razumijevanja u djece kako bi se utvrdila sposobnost djeteta da razumije socijalnu priču (Kokina i Kern, 2010). Primjerice, kriteriji za izbor ispitanika u istraživanju utjecaja socijalnih priča na smanjenje broja nepoželjnih ponašanja (Ozdemir, 2008) bili su: utvrđena dijagnoza poremećaja iz spektra autizma, razvijene vještine verbalne komunikacije i osnovne vještine čitanja. Istraživanje je pokazalo učinkovitost socijalnih priča za smanjenje broja nepoželjnih ponašanja u svih troje ispitanika. U navedenom istraživanju nisu korišteni drugi intervencijski postupci.

Stručnjaci navode dvije ključne komponente uspješnosti u kreiranju socijalnih priča (Charlop i Milstein, 1989): (1) omogućiti djetetu da socijalnu priču čita samo ili da je čita osoba bliska djetetu te (2) osigurati da je socijalna priča prezentirana na djetetu prihvatljiv način te kroz medij koji dijete preferira (audio snimka ili video prikaz).

U skladu s dosadašnjim istraživanjima, u ovom istraživanju su socijalne priče prezentirane putem video modeliranja te je na taj način osigurano održavanje djetetove motivacije na razini koja podržava učenje.

\section{Cilj rada}

Cilj ovog rada je ispitati utjecaj uporabe socijalnih priča putem video modeliranja na poticanje socijalne komunikacije (iniciranja interakcije i odgovorljivosti na interakciju iniciranu od strane vršnjaka) dječaka s visokofunkcionirajućim autizmom.

U skladu s ciljem istraživanja postavljene su dvije hipoteze:

\section{Hipoteza (1):}

Dječak s visokofunkcionirajućim autizmom pokazat će značajno bolje rezultate u učestalosti i 
kvaliteti iniciranja interakcija s vršnjacima nakon izloženosti socijalnim pričama u zadanom vremenskom intervalu.

\section{Hipoteza (2):}

Dječak s visokofunkcionirajućim autizmom pokazat će značajno bolje rezultate u učestalosti i kvaliteti odgovorljivosti na interakciju iniciranu od strane vršnjaka nakon izlaganja socijalnim pričama putem video modeliranja u zadanom vremenskom intervalu.

\section{METODE RADA}

\section{Uzorak ispitanika}

U istraživanju je sudjelovao dječak ( 5 ; 2 godine) s dijagnozom visokofunkcionirajućeg autizma, urednih intelektualnih sposobnosti, koji je na posljednjoj psihološko-logopedskoj procjeni u dobi od 4;9 godina pokazao značajne teškoće u suradnji i interakciji, s najvećim odstupanjima u obilježjima komunikacije i posljedično jezično-govornog razvoja. Dječakovo jezično razumijevanje procijenjeno je na razini lakog zaostajanja. U jezičnoj proizvodnji služio se višečlanim agramatičnim rečenicama, uz povremenu prisustnost eholalije $u$ iskazima. Pokazao je smanjen interes za aktivnosti koje mu sadržajno nisu odgovarale (čitanje priča od strane odrasle osobe) te velik interes za računalnu tehnologiju (laptop, tablet). Dječak je u trenutku provođenja istraživanja bio uključen u redovan dječji vrtić uz podršku pomagača te je u dječjem vrtiću koristio vizualni raspored aktivnosti kao podršku pri prijelazu na sljedeću dnevnu aktivnost.

\section{Opis ispitnog materijala $i$ ispitnog instrumentarija}

Za vrijeme inicijalne i finalne procjene bilježena su komunikacijska sredstva i funkcije, na temelju opservacije djeteta za vrijeme dvosatne slobodne igre u vrtiću. Bilježili su se komunikacijski činovi (opis komunikacijskog čina: "Dijete je prišlo stolu, pogledalo me u oči i pokazalo prema lutki jer je željelo da mu je dodam.”), komunikacijske funkcije (Traženje predmeta, Traženje aktivnosti, Odbijanje, Pozdravljanje, Nadovezivanje, Komentiranje, Traženje informacija, Davanje informacija, Traženje pojašnjenja; imperativna/dekla- rativna) te komunikacijska sredstva (gesta, govor, vokalizacija, pisanje, pogled, facijalna ekspresija, kombinacija više sredstava koja uključuje govor, kombinacija više sredstava koja ne uključuje govor). Za potrebe istraživanja osmišljene su dvije socijalne priče koje su vezane uz podciljeve podučavanja. Socijalne priče sastavljene su od ključnih riječi i izraza koje dječak razumije i izražava u svakodnevnim situacijama ( $u$ redu je, nije u redu, ponekad, želim, ne želim, tužan, sretan). U socijalnim pričama korištene su jednočlane do trinaesteročlane rečenice. Transkripte socijalnih priča čitale su dvije ženske i jedna muška osoba (mačak Tomica, miš Luka i žirafa Mirta). Transkripti su snimljeni programom Audacity 2.1.0. (2015) te prilagođeni potrebama video prikaza. Za potrebe istraživanja napravljen je video prikaz socijalnih priča (u trajanju od 2:23 min.), koji je dao vizualnu formu socijalnim pričama. U video prikazu, dvije se socijalne priče nižu jedna za drugom. Svaki od dva dijela video prikaza započinje prikazom neprimjerenog ponašanja, potom slijedi prikaz ciljanog ponašanja, a naposlijetku se nalazi objašnjenje socijalne prihvatljivosti ponašanja te primjer ciljanog ponašanja ("Nije u redu gurati prijatelja."/ "U redu je ponekad se igrati sam"). Personalizirani životinjski likovi odabrani su prema dječakovim interesima. Budući da dječak pokazuje specifičan interes prema liku mačke (crtani filmovi, plišane i druge igračke) te u simboličkoj igri uvijek glumi lik mačke, životinjski lik mačke u crtanom filmu predstavlja dječaka, njegove reakcije i ponašanja (guranje prijatelja, izražavanje nezadovoljstva i ljutnje). Lik miša Luke predstavlja dječakovog najboljeg prijatelja iz dječjeg vrtića, dječaka s kojim provodi najviše vremena u igri i drugim aktivnostima. Liku Žirafe pridružene su vizualne karakteristike odrasle osobe (naočale, stil odijevanja) s namjerom da navedeni lik predstavlja autoritet dječaku, budući da dijete u igri liku žirafe obično daje roditeljsku ili ulogu odgajatelja. U nastavku slijedi prikaz ključnih scena iz video prikaza (Slika 1) te transkripti socijalnih priča (Dodatak 1)

Dodatak 1. Transkripti socijalnih priča

\section{Uvod}

Mačak Tomica: Bok, ja sam Tomica. Kako se ti zoveš?

Miš Luka: Bok. Ja sam Luka. 
Nepoželjno ponašanje
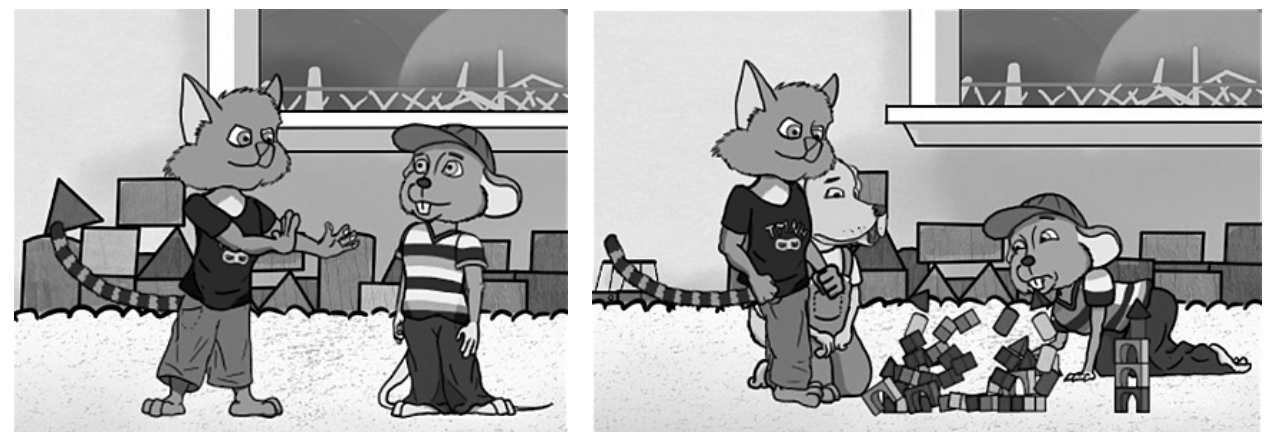

Poželjno (ciljano) ponašanje
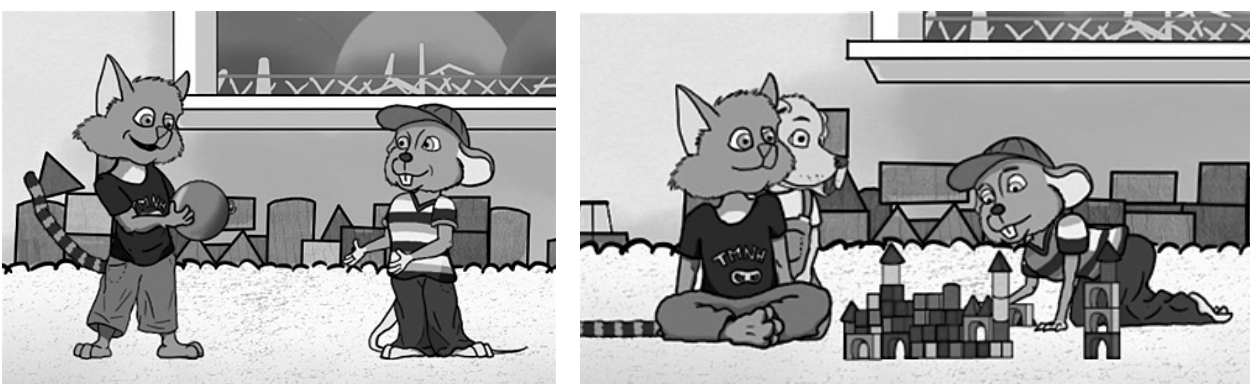

Slika1. Prikaz ključnih scena iz video prikaza

Socijalna priča 1.

Mačak Tomica: Luka, želiš li se igrati sa mnom? Miš Luka: Ne. Ne želim se igrati s tobom.

Mačak Tomica: (Ljuti se i gura ga.)

Žirafa Mirta: U redu je ponekad biti ljut. Nije u redu gurati prijatelja. Ponekad se prijatelji ne žele igrati s nama $i$ žele raditi nešto drugo. $U$ redu je ponekad se igrati sam.

Mačak Tomica: Luka, želiš li se igrati sa mnom?

Miš Luka: Ne. Ne želim se igratis tobom.

Mačak Tomica: A dobro.

Žirafa Mirta: Ponekad se prijatelji ne žele igrati s nama i žele raditi nešto drugo. U redu je ponekad se igrati sam.

Mačak Tomica: Luka, želiš li se igrati sa mnom?

Miš Luka: Da! Idemo se igrati!

Žirafa Mirta: Tomica je sretan. Lijepo je igrati se s prijateljima.

Socijalna priča 2.

Miš Luka: Tomice, mogu li se igrati s tobom?

Mačak Tomica: Ne.

Miš Luka: (Ljuti se i gura ga.)

Žirafa Mirta: U redu je ponekad biti ljut. Nije u redu gurati prijatelja. Ponekad se ne želimo igrati s prijateljima i dijeliti igračke. U redu je ponekad se igrati sam.

Miš Luka: Tomice, mogu li se igrati s tobom?

Mačak Tomica: Ne.
Žirafa Mirta: Ponekad se ne želimo igrati s prijateljima i dijeliti igračke. U redu je ponekad se igrati sam.

Miš Luka: Tomice, mogu li se igrati s tobom?

Mačak Tomica: Da.

Žirafa Mirta: Lijepo je igrati se s prijateljima $i$ dijeliti igračke.

Za vrijeme i nakon prezentacije video prikaza djetetu bilježeni su: dan, interes za video prikaz, ponašanje za vrijeme gledanja video prikaza te ponašanje nakon gledanja video prikaza.

\section{Postupak}

Istraživanje je provedeno u redovnom dječjem vrtiću u Zagrebu, uz suglasnost majke i osoblja dječjeg vrtića, u trajanju od 7 tjedana. U radu $\mathrm{s}$ dječakom primjenjivane su socijalne priče putem video modeliranja. Cilj rada bio je ispitivanje učinaka socijalnih priča na vještine socijalne interakcije, budući da je kod dječaka utvrđena smanjena učestalost $\mathrm{i}$ kvaliteta iniciranih socijalnih interakcija kao i smanjena učestalost i kvaliteta primjerenih odgovora na interakciju iniciranu od strane vršnjaka. Najveći naglasak stavljen je na vještine socijalne interakcije čija je pojavnost najučestalija za vrijeme slobodne igre s vršnjacima (isključivo djeca redovne skupine dječjeg vrtića čiji je dječak polaznik). 
Ciljana ponašanja (iniciranje interakcije s vršnjacima i odgovorljivost na interakciju iniciranu od strane vršnjaka) identificirana su na osnovu opservacije dječaka te razgovora s roditeljima dječaka. Kriterij za odabir ciljanih ponašanja bile su vještine socijalne interakcije u kojima se javlja visoka učestalost javljanja neprimjerenih odgovora od strane dječaka (nepoželjna ponašanja: guranje, udaranje, bacanje po podu, plač).

U prvoj fazi istraživanja provedena je inicijalna procjena ponašanja dječaka u trajanju od tjedan dana, po 2 sata dnevno, za vrijeme slobodne igre u vrtiću. Procjena se temeljila na opservaciji dječakovih ponašanja u interakciji s vršnjacima. Svaki komunikacijski čin dječaka zabilježen je u tablici komunikacijskih sredstava i funkcija koja je izrađena za potrebe istraživanja.

Nakon toga, uslijedio je period podučavanja ( 5 tjedana) tj. izlaganja dječaka video prikazima socijalnih priča koje su formirane u skladu s ciljevima istraživanja. Video prikazi su sadržavali personalizirane crtane likove u ciljanoj međusobnoj interakciji i bili su popraćeni kratkim socijalnim pričama vezanim uz ciljeve podučavanja. Podučavanje dječaka odvijalo se u zasebnom prostoru predškolske ustanove, čiji je dječak polaznik. Dječak je bio odvojen od druge djece i djelatnika (uz prisustvo ispitivača) te izložen video prikazima socijalnih priča svakog dana $\mathrm{u}$ isto vrijeme, neposredno prije slobodne igre s vršnjacima. Dječaku je omogućeno gledanje jednog video prikaza u danu tijekom prva dva tjedna podučavanja, nakon čega je slijedilo postupno smanjivanje broja gledanih video prikaza tijekom tjedna. Treći i četvrti tjedan ispitivanja dječak je bio izložen video prikazu socijalnih priča četiri dana u tjednu, a posljednjeg tjedna podučavanja tri dana u tjednu. Dječaku nije omogućeno više od jedne reprodukcije video prikaza socijalnih priča u danu. Kako bi se dječaku objasnilo smanjenje broja gledanih video prikaza socijalnih priča u tjednu, u dječakov vizualni raspored aktivnosti dodane su dvije nove slike vezane uz izloženost video prikazima socijalnih priča: (1) slikom glavnih likova iz video prikaza označeni su dani u kojima je dječaku bilo omogućeno gledanje video prikaza socijalnih priča te (2) slikom glavnih likova iz video prikaza koja je bila prekrivena košuljicom zabrane aktivnosti označeni su dani u kojima dječaku nije bilo omo- gućeno gledanje video prikaza socijalnih priča. Po završetku faze podučavanja, slijedila je ponovljena (finalna) procjena zavisnih varijabli, u trajanju od tjedan dana, po 2 sata dnevno, za vrijeme slobodne igre u vrtiću. Korišten je princip opservacije i bilježenja istovjetan onom u inicijalnoj procjeni.

\section{REZULTATI ISTRAŽIVANJA I RASPRAVA}

\section{Prikaz rezultata inicijalne procjene po danima praćenja}

Svrha djetetove komunikacije u najvećem broju slučajeva tijekom prvog dana inicijalne procjene bila je Nadovezivanje (25\%), Komentiranje (25\%) i Davanje informacija (25\%), slijede Odbijanje $(12,5 \%)$ i Pozdravljanje (12,5\%). Prvog dana inicijalne procjene dijete nije komuniciralo u svrhu Traženja predmeta, Traženja aktivnosti, Traženja informacija i Traženja pojašnjenja.

Tijekom drugog dana inicijalne procjene, svrha djetetove komunikacije u najvećem broju slučajeva bila je Davanje informacija (57,14\%). Slijede Pozdravljanje (14,29\%) i Traženje aktivnosti $(14,29 \%)$ te Komentiranje (14,29\%). Dijete nije komuniciralo u druge svrhe.

Svrha djetetove komunikacije u najvećem broju slučajeva tijekom trećeg dana inicijalne procjene bila je Traženje informacija (28,57\%) i Davanje informacija (28,57\%). Slijede Odbijanje (14,29\%), Pozdravljanje (14,29\%) i Komentiranje (14,29\%).

Tijekom četvrtog dana inicijalne procjene svrha djetetove komunikacije u najvećem broju slučajeva bila je Pozdravljanje $(28,57 \%)$ i Traženje informacija (28,57\%). Slijede Odbijanje (14,29\%), Nadovezivanje $(14,29 \%)$ i Davanje informacija (14,29\%).

Posljednjeg dana inicijalne procjene svrha djetetove komunikacije u najvećem broju slučajeva bila je Kometiranje (33\%). Slijede Traženje predmeta (16,67\%), Pozdravljanje (16,67\%), Traženje informacija $(16,67 \%)$ i Davanje informacija $(16,67 \%)$ (Tablica 1)

\section{Prikaz rezultata finalne procjene po danima praćenja}

Svrha djetetove komunikacije u najvećem broju slučajeva tijekom prvog dana finalne procjene bila 
Tablica 1. Prikaz frekvencija komunikacijskih činova inicijalne procjene

\begin{tabular}{|c|c|c|c|c|c|c|c|c|c|c|}
\hline \multirow{3}{*}{ Komunikacijski čin (funkcija) } & \multicolumn{10}{|c|}{ Dan inicijalne procjene } \\
\hline & \multicolumn{2}{|c|}{1.} & \multicolumn{2}{|c|}{2.} & \multicolumn{2}{|c|}{3.} & \multicolumn{2}{|c|}{4.} & \multicolumn{2}{|c|}{5.} \\
\hline & (f1) & $(\%)$ & (f1) & $(\%)$ & (f1) & $(\%)$ & (f1) & $(\%)$ & (f1) & $(\%)$ \\
\hline Traženje predmeta & 0 & 0,00 & 0 & 0,00 & 0 & 0,00 & 0 & 0,00 & 1 & 16,67 \\
\hline Traženje aktivnosti & 0 & 0,00 & 1 & 14,29 & 0 & 0,00 & 0 & 0,00 & 0 & 0,00 \\
\hline Odbijanje & 1 & 12,50 & 0 & 0,00 & 1 & 14,29 & 1 & 14,29 & 0 & 0,00 \\
\hline Pozdravljanje & 1 & 12,50 & 1 & 14,29 & 1 & 14,29 & 2 & 28,57 & 1 & 16,67 \\
\hline Nadovezivanje & 2 & 25,00 & 0 & 0,00 & 0 & 0,00 & 1 & 14,29 & 0 & 0,00 \\
\hline Komentiranje & 2 & 25,00 & 1 & 14,29 & 1 & 14,29 & 0 & 0,00 & 2 & 33,33 \\
\hline Traženje informacija & 0 & 0,00 & 0 & 0,00 & 2 & 28,57 & 2 & 28,57 & 1 & 16,67 \\
\hline Davanje informacija & 2 & 25,00 & 4 & 57,14 & 2 & 28,57 & 1 & 14,29 & 1 & 16,67 \\
\hline Traženje pojašnjenja & 0 & 0,00 & 0 & 0,00 & 0 & 0,00 & 0 & 0,00 & 0 & 0,00 \\
\hline Suma & 8 & 100 & 7 & 100 & 7 & 100 & 7 & 100 & 6 & 100 \\
\hline Ukupna suma & & & & & & & & & & \\
\hline
\end{tabular}

je Komentiranje $(28,57 \%)$ i Davanje informacija (28,57\%), slijede Traženje predmeta (14,29\%) i Traženje aktivnosti (14,29\%). Dijete je prvog dana finalne procjene komuniciralo još i u svrhu Traženja informacija (7,14\%).

Tijekom drugog dana finalne procjene, svrha djetetove komunikacije u najvećem broju slučajeva bila je Davanje informacija (38,46\%). Slijedi Traženje informacija $(15,38 \%)$, Traženje predmeta (15,38\%), Traženje aktivnosti (15,38\%), Pozdravljanje (7,69\%) i Nadovezivanje (7,69\%). Dijete nije komuniciralo u druge svrhe.

Svrha djetetove komunikacije u najvećem broju slučajeva tijekom trećeg dana finalne pro- cjene bila je Davanje informacija $(33,33 \%)$ i Traženje informacija (22,22\%). Slijede Traženje predmeta $(11,11 \%)$, Traženje aktivnosti $(11,11 \%)$, Nadovezivanje $(11,11 \%)$ te Pozdravljanje $(11,11 \%)$.

Tijekom četvrtog dana finalne procjene svrha djetetove komunikacije u najvećem broju slučajeva bila je Davanje informacija (55,56\%). Slijede Pozdravljanje (11,11\%), Komentiranje (11,11\%), Nadovezivanje $(11,11 \%)$ i Traženje informacija $(12,50 \%)$.

Posljednjeg dana finalne procjene svrha djetetove komunikacije u najvećem broju slučajeva bila je Davanje informacija (41,66\%), Traženje infor-

Tablica 2. Prikaz frekvencija komunikacijskih činova finalne procjene

\begin{tabular}{|c|c|c|c|c|c|c|c|c|c|c|}
\hline \multirow[t]{3}{*}{ Komunikacijski čin (funkcija) } & \multicolumn{10}{|c|}{ Dan finalne procjene } \\
\hline & \multicolumn{2}{|c|}{1.} & \multicolumn{2}{|c|}{2.} & \multicolumn{2}{|c|}{3.} & \multicolumn{2}{|c|}{4.} & \multicolumn{2}{|c|}{5.} \\
\hline & (f2) & $(\%)$ & (f2) & $(\%)$ & (f2) & $(\%)$ & (f2) & $(\%)$ & (f2) & $(\%)$ \\
\hline Traženje predmeta & 2 & 14,29 & 2 & 15,38 & 1 & 11,11 & 0 & 0,00 & 2 & 16,66 \\
\hline Traženje aktivnosti & 2 & 14,29 & 2 & 15,38 & 1 & 11,11 & 0 & 0,00 & 1 & 8,33 \\
\hline Odbijanje & 0 & 0,00 & 0 & 0,00 & 0 & 0,00 & 0 & 0,00 & 0 & 0,00 \\
\hline Pozdravljanje & 1 & 7,14 & 1 & 7,69 & 1 & 11,11 & 1 & 11,11 & 1 & 8,33 \\
\hline Nadovezivanje & 0 & 0,00 & 1 & 7,69 & 1 & 11,11 & 1 & 11,11 & 0 & 0,00 \\
\hline Komentiranje & 4 & 28,57 & 0 & 0,00 & 0 & 0,00 & 1 & 11,11 & 1 & 8,33 \\
\hline Traženje informacija & 1 & 7,14 & 2 & 15,38 & 2 & 22,22 & 1 & 11,11 & 2 & 16,66 \\
\hline Davanje informacija & 4 & 28,57 & 5 & 38,46 & 3 & 33,33 & 5 & 55,56 & 5 & 41,66 \\
\hline Traženje pojašnjenja & 0 & 0,00 & 0 & 0,00 & 0 & 0,00 & 0 & 0,00 & 0 & 0,00 \\
\hline Suma & 14 & 100 & 13 & 100 & 9 & 100 & 9 & 100 & 12 & 100 \\
\hline Ukupna suma & & & & & & & & & & \\
\hline
\end{tabular}


macija $(16,16 \%)$ i Traženje predmeta $(16,66 \%)$. Slijede Traženje aktivnosti (8,33\%), Pozdravljanje $(8,33 \%)$ i Komentiranje $(8,33 \%)$ (Tablica 2$)$.

Ukupan broj komunikacijskih činova u finalnoj procjeni se, $u$ odnosu na inicijalnu procjenu, povećao za $62,86 \%$ (Tablica 3 ), čime je potvrđen pozitivan utjecaj socijalnih priča putem video modeliranja na učestalost ciljanih vještina socijalne interakcije kod dječaka s visokofunkcionirajućim autizmom (Slika 2).

Tablica 3. Prikaz frekvencija komunikacijskih činova inicijalne i finalne procjene

\begin{tabular}{|l|c|c|}
\hline & Frekvencije & Postotni udio \\
\hline Inicijalna procjena & 35 & $38,04 \%$ \\
\hline Finalna procjena & 57 & $61,95 \%$ \\
\hline Indeks (I) & - & $62,86 \%$ \\
\hline
\end{tabular}

Napomena: Indeks je relativan broj koji se dobije uspoređivanjem dviju ili više frekvencija vremenskog niza. Izračun indeksa vršio se s bazom usporedbe $f_{2}\left(f_{1}=\right.$ razlika frekvencija inicijalne $\mathrm{i}$ finalne procjene; $f_{2}=$ ukupna frekvencija komunikacijskih činova inicijalne procjene) (Mejovšek, 2003).

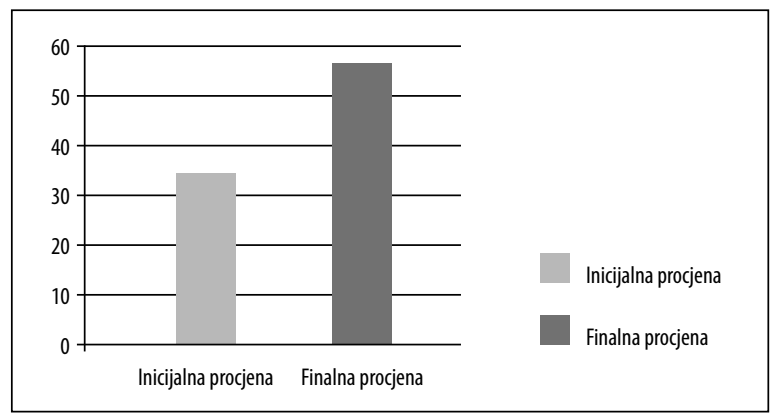

Slika 2. Prikaz frekvencija komunikacijskih činova za vrijeme inicijalne i finalne procjene

Dječak je na finalnoj procjeni u dobi od 5,3 pokazao napredak u učestalosti i kvaliteti interakcija s vršnjacima (Tablica 4). Analiza rezultata finalne procjene pokazuje pozitivan pomak u vještinama socijalne interakcije djeteta u vidu sve većeg broja iniciranja interakcija s vršnjacima (povećanje učestalosti Traženja predmeta, Traženja aktivnosti i Traženja informacija). Komuniciranje za imperativne funkcije kod dječaka se povećalo za $550 \%$ $\mathrm{u}$ usporedbi rezultata inicijalne i finalne procjene. Komuniciranje za deklarativne funkcije povećalo se za 33\% odnosu na ukupni rezultat ispitivanja komunikacijskih funkcija djeteta (Tablica 5).

Tablica 4. Prikaz frekvencija komunikacijskih svrha za vrijeme inicijalne i finalne procjene

\begin{tabular}{|l|c|c|c|c|}
\hline \multirow{2}{*}{$\begin{array}{l}\text { Komunikacijska } \\
\text { svrha }\end{array}$} & \multicolumn{2}{|c|}{ Inicijalna procjena } & \multicolumn{2}{c|}{ Finalna procjena } \\
\cline { 2 - 5 } & (f1) & $(\%)$ & (f2) & (\%) \\
\hline $\begin{array}{l}\text { Imperativna } \\
\text { funkcija }\end{array}$ & 2 & $5,71 \%$ & 13 & $22,81 \%$ \\
\hline $\begin{array}{l}\text { Deklarativna } \\
\text { funkcija }\end{array}$ & 33 & $94,29 \%$ & 44 & $77,19 \%$ \\
\hline Suma & 35 & $100 \%$ & 57 & 100 \\
\hline
\end{tabular}

Tablica 5. Indeks vrijednost u usporedbi učestalosti korištenja imperativnih i deklarativnih funkcija inicijalne i finalne procjene

\begin{tabular}{|l|c|}
\hline Procjena komunikacijske funkcije & Indeks (I) \\
\hline Imperativna funkcija & $550 \%$ \\
\hline Deklarativna funkcija & $33 \%$ \\
\hline
\end{tabular}

Usporedbom rezultata inicijalne i finalne procjene uočena je stagnacija djeteta u Pozdravljanju (generalizirana vještina) te Traženju pojašnjenja (vještina koja u ovom istraživanju nije podučavana). Uzimajući u obzir učinkovitost metode socijalnih priča, bilo bi korisno osmisliti socijalnu priču za podučavanje vještine Traženje pojašnjenja u kreiranju daljnjih ciljeva za podučavanje dječaka.

$\mathrm{Na}$ temelju dobivenih rezultata prihvaća se hipoteza (1), da će dječak s visokofunkcionirajućim autizmom pokazati značajno bolje rezultate $\mathrm{u}$ učestalosti i kvaliteti iniciranih interakcija s vršnjacima nakon izloženosti socijalnim pričama putem video modeliranja u zadanom vremenskom intervalu, što je vidljivo već tijekom prvog tjedna podučavanja, gdje dječak prilazi drugom dječaku iz skupine i pita ga: "F., hoćemo se igrati trčati i loviti?". Nakon negativnog odgovora od strane vršnjaka, dječak prilazi istraživaču i govori: "Ja ću trčati sam!". U navedenom primjeru jasno se vidi da je dječak inicirao interakciju s vršnjakom, a umjesto nepoželjnim ponašanjem po dobivenom negativnom odgovoru, reagirao je na način na koji je podučen ("Ponekad se prijatelji ne žele igrati s nama i žele raditi nešto drugo. $U$ redu je ponekad se igrati sam."). Tijekom trećeg tjedna podučavanja, nakon što je svjedočio guranju djevojčice iz skupine govori: "Ne smije se gurati curicu. Nije u redu gurati prijatelja!", gdje je prisutna uporaba 
rečenice identične onoj korištenoj u video prikazu ("Nije u redu gurati prijatelja."), a dječak je koristi svrhovito i prikladno situaciji. Analiza transkripata pokazala je da se tijekom i nakon intervencije smanjio broj nepoželjnih ponašanja dječaka. Dječak, čija je inicijalna reakcija na interakcije inicirane od strane vršnjaka, u najvećem broju slučajeva tijekom inicijalne procjene, bila izostanak odgovora s posljedičnim izražavanjem nepoželjnih ponašanja (odgurivanje, odlazak od komunikacijskog partnera), napredovao je tijekom podučavanja te je u finalnoj procjeni uočeno korištenje novih komunikacijskih svrha uz povećanje učestalosti korištenja Davanja informacija.

Rezultati pokazuju napredak na funkciji Davanje informacija u svrhu odgovaranja na interakcije inicirane od strane vršnjaka, za $130 \%$ (Tablica 6), što je jasno vidljivo iz sljedećeg primjera: Dječak slaže puzzle. Prilazi mu drugi dječak iz skupine i pita ga: "Što to radiš?" Dječak odgovara: "Radim slažem puzzle."

Tablica 6. Omjer korištenja komunikacijske svrhe Davanje informacija za vrijeme inicijalne i finalne procjene

\begin{tabular}{|l|c|c|}
\hline Davanje informacija & Frekvencija & Indeks (I) \\
\hline Inicijalna procjena & $\mathrm{f} 1=10$ & \multirow{2}{*}{$130 \%$} \\
\cline { 1 - 2 } Finalna procjena & $\mathrm{f} 2=23$ & \\
\hline
\end{tabular}

Najveći broj nepoželjnih ponašanja različite topografije zabilježen je tijekom inicijalne procjene. U periodu podučavanja, kao i za vrijeme finalne procjene, dječak nije izražavao nepoželjna ponašanja za vrijeme slobodne igre u vrtiću, što je u skladu s istraživanjima istog konstrukta, koja dokazuju da su socijalne priče učinkovitije u smanjenju broja nepoželjnih ponašanja nego u podučavanju poželjnih oblika ponašanja (Kokina i Kern, 2010). Primjer nalazimo u sljedećoj situaciji zabilježenoj tijekom prvog dana inicijalne procjene: Dječak slaže puzzle. Po završetku, prilaze mu druga dva dječaka iz skupine i govore: “Sad je naš red!". Dječak ih gura i ljuti se. Viče: "Neću.". Tijekom trećeg tjedna finalne procjene, vidljiva je jasna promjena u dječakovu ponašanju: Dječak i djevojčica iz skupine igraju se telefonima. Dječak pita djevojčicu: "L., daš mi taj telefon, lijepo zamolim?" Djevojčica odgovara: "Daš ti meni svoj?”. Dječak odvraća: “Dobro (daje svoj telefon djevojčici i uzima njen telefon). U navedenim primjerima pred dječaka je postavljen zahtjev za djeljenjem igračaka. U prvoj opisanoj situaciji dječak odgovara nepoželjnim oblikom ponašanja (guranje, ljutnja). U drugoj opisanoj situaciji dječakovo je ponašanje modelirano video prikazom (Žirafa: "Lijepo je igrati se s prijateljima i dijeliti igračke.").

Budući da su socijalne priče strukturirane na način da prvo daju prikaz nepoželjnog ponašanja u ciljanoj socijalnoj situaciji nakon čega slijedi prikaz poželjnog ponašanja, posljedica koju odražava pozitivno ponašanje te naposlijetku objašnjenje socijalne prihvatljivosti ponašanja, pretpostavka je da je dječaku kao pojačanje (pozitivna posljedica koja povećava vjerojatnost pojave istog ponašanja u budućnosti) služila socijalna pohvala, odnosno, emocionalna reakcija komunikacijskog partnera u video prikazu. Dječak je u više navrata tijekom podučavanja i finalne procjene verbalizirao i modelirao upravo (emocionalnu) reakciju komunikacijskog partnera u video prikazu. Primjer nalazimo već tijekom prvog tjedna podučavanja, u sljedećoj situaciji: Dječaku prilazi drugi dječak iz skupine i uzima mu fen iz ruke. Dječak viče: "Vrati fen, to je moje!" Drugi dječak ga gura. Dijete se odmiče i govori: "Žirafa je rekla ne smijemo gurati prijatelja. Ja tužan sad!" Prilazi mu dječak koji ga je gurnuo i govori: "Žao mi je, neću više gurati te (vraća mu fen)." Odmicanje od dječaka, facijalnu ekspresiju (tuga) i korištenu frazu "...ne smijemo gurati prijatelja!", dječak je iskoristio svrhovito, a ponašanje je pojačala emocionalna reakcija vršnjaka (isprika, dobivanje željenog oduzetog predmeta).

Suvremena istraživanja govore $\mathrm{u}$ prilog tome da su socijalne priče učinkovitije ukoliko im je dijete izloženo neposredno prije uključivanju u ciljanu aktivnost, što je bio slučaj u ovom istraživanju. Bilježenjem ponašanja za vrijeme i neposredno nakon izloženosti video prikazu, dobivene su dječakove stupnjevite razrade nadolazećih, očekivanih situacija. Tako dječak tijekom prvog tjedna podučavanja komentira likove i prostor kojima je izložen ("Žirafa ima naočale.”, "Djeca se igraju s kockicama.”, "Napravit ćemo dvorac."). Tijekom četvrtog tjedna podučavanja pokazuje razumijevanje video prikaza kojemu je izloženo te planira nadolazeću aktivnost igre: "Ponekad se prijatelji igraju zajedno. Nije u redu gurati prija- 
telja. Prijatelj tužan. I onda se idemo igrati u sobu?”. Tijekom četvrtog tjedna podučavanja smanjuje se dječakova potreba za komentiranjem tijekom i neposredno nakon izloženosti video prikazu, a povećava se svrsishodna primjena naučenog za vrijeme slobodne igre s vršnjacima, što je jasno vidljivo iz sljedećeg primjera, zabilježenog tijekom četvrtog tjedna podučavanja: F. i dječak se igraju kockicama. Grade kuću za dinosaura. F. ruši kućicu (glumi da dinosaur skače po kućici). Dječak stavlja ruke preko kućice da je zaštiti. F. ga gura. Dječak: "Nije u redu srušiti i gurati prijatelja! F. je srušio i gurao!" Odgajateljica: "Pusti F., idi se igrati nešto drugo". Dječak: "Neću drugo sam. Želim s prijateljima."

Pozitivni pomaci na području socijalnih interakcija u dječaka mogu se objasniti rezultatima istraživanja (Gray, 2000), koja govore u prilog tome da su socijalne priče koje opisuju jednostavna ponašanja učinkovitije od onih koje opisuju složena ponašanja te da su učinkovitije ukoliko koriste dodatne vizualne ilustracije (video model), što je bio slučaj u ovom istraživanju. Također, prilikom korištenja takvih priča može doći do lakše generalizacije ponašanja. Sljedeći primjeri govore u prilog tome: Dječak crta. Prilazi mu djevojčica iz skupine i pita: "Mogu li i ja crtati?" Dječak: "Uzmi papir tamo (pokazuje) i uzmi bojicu žute!”, djevojčica iz skupine sjeda do dječaka za stol. Crtaju. Dječak: "A., što si to crtala?" A.: "Oblake i sunce." "A ti?" "Nacrtao sam cvijet!"; Dječaku je pala kutija s dinosaurima. Viče: "Ojoj! Palo je! F., dođi, pomozi!" F.: "Nemoj spremati, idemo se s tim igrati." Dječak: "Da, idemo se igrati!" Igraju se na podu s dinosaurima. Uočljiv je izostanak nepoželjnih ponašanja te značajno viša kvaliteta odgovora na interakciju iniciranu od strane vršnjaka s jasno vidljivim utjecajem socijalnih priča u korištenim frazama ("Da, idemo se igrati!") i modeliranim ponašanjima, koje je dijete uspješno generaliziralo.

$\mathrm{Na}$ temelju dobivenih rezultata prihvaća se hipoteza (2) da će dječak s visokofunkcionirajućim autizmom pokazati značajno bolje rezultate $u$ učestalosti i kvaliteti odgovorljivosti na interakciju iniciranu od strane vršnjaka nakon izloženosti socijalnim pričama putem video modeliranja u zadanom vremenskom intervalu.

Rezultate ovog istraživanja potrebno je sagledati s oprezom. Kako se radi o nacrtu jednostavne izmjene faza na pojedincu (A-B nacrt) potrebno je $s$ oprezom tumačiti promjene u ponašanju koje se javljaju u fazi B. Naime, na navedene promjene mogu utjecati i drugi činitelji izvan eksperimentalne kontrole, primjerice maturacija, logopedska terapija u koju je dječak uključen, povećana svijest okoline o teškoćama dječaka te i moguća promjena reagiranja okoline na određena ponašanja dječaka i slično. U ovom istraživanju navedeno se pokušalo kontrolirati kratkim vremenskim intervalom u kojem se istraživanje provodi ( 7 tjedana) te se u skladu s tim pokušao kontrolirati utjecaj maturacije. Međutim, važno je rezultate sagledati s oprezom zbog nemogućnosti da se u potpunosti uklone prijetnje unutarnjoj valjanosti.

\section{Praktične implikacije i smjernice za buduća istraživanja}

Metoda socijalnih priča bitan je dio intervencijskih programa za djecu s poremećajem iz spektra autizma.

Personalizirane socijalne priče jednostavne su za izradu, prenosive, intervali podučavanja su vrlo kratki, a dugoročni rezultati brzo vidljivi. Osim toga, socijalne priče pružaju potrebnu podršku vizualno orijentiranim učenicima. Kreiraju se individualno, sukladno djetetovim interesima. $\mathrm{Na}$ taj način osiguravaju razinu motivacije potrebnu za uspješno učenje. U izradi socijalne priče odabir ključnih riječi usklađuje se s djetetovim receptivnim riječnikom. Na taj način kreira se situacija učenja u kojoj dijete socijalnu priču u potpunosti razumije.

Te kvalitete socijalnih priča osigurale su napredak djeteta i pozitivne rezultate ovog istraživanja, prvog istraživanja učinkovitosti socijalnih priča u podučavanju socijalnih vještina djece s poremećajem iz spektra autizma u Republici Hrvatskoj. $\mathrm{S}$ obzirom na to da su suvremena istraživanja nekonzistentna u pogledu učinkovitosti socijalnih priča, ovaj je rad važan dokaz koji govori u prilog korištenja socijalnih priča u podučavanju djece $s$ poremećajem iz spektra autizma.

U Republici Hrvatskoj socijalne priče se nedostatno koriste u kliničkom radu te ne postoji dovoljan broj educiranih stručnjaka za njihovu implementaciju u intervencijske programe usmjerene 
na podučavanje djece s poremećajem iz spektra autizma. Ovaj je rad primjer dobre prakse u radu $\mathrm{s}$ djecom s visokofunkcionirajućim autizmom, a teorijska polazišta i metodološki principi korišteni u ovom radu mogu biti dobar putokaz stručnjacima u izradi programa za djecu s visokofunkcionirajućim autizmom te polazište za buduća istraživanja.

\section{ZAKLJUČAK}

Cilj rada bio je ispitati utjecaj socijalnih priča putem video modeliranja na vještine socijalne interakcije dječaka s visokofunkcionirajućim autizmom. Istraživanje se sastojalo od kvantitativnog i kvalitativnog dijela.

Rezultati istraživanja pokazali su povećanje ukupnog broja komunikacijskih činova kod dječaka. Dječak je komunicirao pretežno govorom za deklarativne funkcije u svim fazama istraživanja. Tijekom finalne procjene uočen je pozitiv- ni pomak u upotrebi komunikacijskih funkcija: Traženje predmeta, Traženje aktivnosti, Traženje informacija. Ovi rezultati potvrđuju hipotezu (1) prema kojoj će dječak s visokofunkcionirajućim autizmom pokazati značajno bolje rezultate u učestalosti i kvaliteti iniciranja interakcija s vršnjacima nakon izloženosti socijalnim pričama u zadanom vremenskom intervalu. Tijekom i nakon istraživanja došlo je do smanjenja broja nepoželjnih ponašanja kod dječaka. Na varijabli Odgovorljivost na interakciju iniciranu od strane vršnjaka dječak je postigao značajno bolji rezultat $u$ odnosu na rezultate inicijalne procjene, čime je potvrđena hipoteza (2) prema kojoj će dječak s visokofunkcionirajućim autizmom pokazati značajno bolje rezultate $u$ učestalosti i kvaliteti odgovorljivosti na interakciju iniciranu od strane vršnjaka nakon izlaganja socijalnim pričama putem video modeliranja u zadanom vremenskom intervalu. 
Magdalena Jančec, Sanja Šimleša, Jasmina Frey Škrinjar: Poticanje socijalne interakcije putem socijalnih priča u dječaka s poremećajem iz...

\section{LITERATURA}

American Psychiatric Association (1994): Diagnostic and Statistical Manual of Mental Disorders: DMS-IV, Washington: American Psychiatric Association.

American Psychiatric Association (2013): Highlights of Changes from DSM-IV-TR to DSM-5 (http://www.psych. org/practice/dsm/dsm5) (15.02.2015.).

Atwood, T. (2010): Aspergerov sindrom - vodič za roditelje i stručnjake. Jastrebarsko: Naklada Slap.

Baroh-Cohen, S. (2010): Empathizing, systemizing, and the extreme male brain theory od autism. Progress in Brain Research, 186, 167-175.

Bellini, S., Akullian, J. (2007): A Meta-Analysis of Video Modeling and Video Self-Modeling Interventions for Children and Adolescents with Autism Spectrum Disorders, Exceptional Children, 73, 3.

Charlop, M. H., Milstein, J. P. (1989): Teaching autistic children conversational speech using video modeling, Journal of Applied Behavior Analysis, 22,3, 275-285.

Dawson, G., Toth, K., Abbot, R., Osterling, J., Munson, J., Estes, A., Liaw, J. (2004): Early Social Attention Impairments in Autism: Social Orienting, Joint Attention and Attention to Distress, Developmental Psychology, 40, 2, 271-283.

Gray, C. (1994): The New Social Story Book (Illustrated Edition). Arlington: Future Horizons.

Gray, C. (1998): Social stories and comic strip conversations with students with Asperger syndrome and highfunctioning autism. U: Schopler, E., Mesibov, L., Kunce, J. (ur.) Asperger syndrome and high-functioning autism? New York: Plenum Press.

Gray, C. (2000): The New Social Story Book (Illustrated Edition). Arlington: Future Horizons.

Grynszpan, O., Weiss, P. L., Perez-Diaz, F., Gal, E. (2013): Innovative Technology-based Interventions for Autism Spectrum Disorders: A Meta-Analysis, Autism-International Journal of Research and Practice, 18, 4, 346-361.

Gutstein, S. E., Whitney, T. (2002): Asperger Syndrome and the development of social competence, Focus on Autism and Other Developmental Disabilities, 17, 3, 161-171.

Hobson, P. R., Meyer, J. A. (2005): Foundations for self and other: a study in autism, Developmental Science, 8, 6, 481-491.

Kokina, A., Kern, L. (2010): Social Story Interventions for Students with Autism Spectrum Disorders: A Meta Analysis, Journal of Autism and Developmental Disorders, 40, 812-826.

LeBlanc, L., A., Coates, A. (2003): Using Video Modeling and Reinforcement to Teach Perspective-Taking Skills to Children With Autism, Journal of Applied Behavior Analysis, 36, 2.

Ljubešić, M., Cepanec, M. (2012): Rana komunikacija: u čemu je tajna?, Logopedija, 3, 1, 35-45.

Mejovšek, M. (2003): Uvod u metode znanstvenog istraživanja u društvenim i humanističkim znanostima, Jastrebarsko: Naklada Slap.

Moldin, S. O., Rubenstein, J. L. R. (2006): Understanding Autism: From Basic Neuroscience to Treatment, Boca Raton: CRC Press.

Murray, D. S., Creaghead, N. A., Manning-Courtney, P. (2008): The relationship between joint attention and language in childrens with autism spectrum disorders, Focus on Autism and Other Developmental Disabilities, 23, 5-14.

Nikopoulos, C. K., Keenan, M. (2006): Video modeling and behaviour analysis: A guide for teaching social skills to children with autism. London: Jessica Kingsley Publishers.

O’Hara, M. (2010): Using Social Stories To Teach Social Skills: A Proffesional's Guide. Pittsburg: University of Pittsburg.

Ozdemir, S. (2008): The effectiveness of social stories on decreasing disruptive behaviors in children with autism: three case studies, Journal of Autism and Developmental Disorders, 38, 9, 1689-1696. 
Prelock, P.A., McCauley, R. J. (2012). Treatment of Autism Spectrum Disorders: Evidence-Based Intervention Strategies for Communication and Social Interaction. Baltimore: Paul H. Brookes Publishing.

Reynhout, G., Carter, M. (2006): Social Stories for Children with Disabilities, Journal of Autism and Developmental Disorders, 36, 445-469.

Reynhout, G., Carter, M. (2007): Social Story efficacy for a child with autism spectrum disorder and moderate intellectual disability, Focus on Autism and Other Developmental Disabilities, 22, 3, 173-182.

Rubin, E., Lennon, L. (2004): Challenges in Social Communication in Asperger Syndrome and High-Functioning Autism, Topics in Language Disorder, 24, 4, 271-285.

Sansosti, F. J., Powell-Smith, K. A. (2008): Using Computer-Presented Social Stories and Video Models to Increase the Social Communication Skills of Children With High-Functioning Autism Spectrum Disorders, Journal of Positive Behavior Interventions, 10.

South M., Ozonoff S., McMahon M. W. (2007): The relationship between executive functioning, central coherence, and repetitive behaviors in the high functioning autism spectrum, Autism, 11, 5, 437-451.

Tager-Flushberg, H. (2007): Evaluating the Theory-of-Mind Hypothesis of Autism, Current Directions in Psychological Science, 16, 313-315.

\title{
THE ENCOURAGEMENT OF SOCIAL INTERACTION BY MEANS OF SOCIAL STORIES IN A BOY WITH AUTISM SPECTRUM DISORDER
}

\begin{abstract}
Social Stories are short stories that have been written and adapted for children with autism spectrum disorders (ASD). Social Stories are used to improve children's social and/or communication skills by teaching them appropriate behaviors in social situations. Social Stories are a very common intervention option for children with ASD. Their common goal is to reduce disruptive behaviors and teach social skills. Current research has not yet scientifically confirmed the effectiveness of using Social Stories as a means of improving the social skills of children with ASD. The main goal of this study is to test the influence of using Social Stories combined with a video modelling approach as a treatment option for social interaction skills in a boy with highfunctioning autism. This is the first case study of Social Stories effectiveness in Croatia. The participant was a boy (5,2), diagnosed with high-functioning autism. Social Stories were combined with video modelling to teach social interaction skills. In order to achieve the objective of the study, a survey consisting of quantitative and qualitative work was conducted. The quantitative part of the study presents the results of measurements of the frequency of initiated social interactions of the participant, and measurement of the frequency of social responsiveness to interaction initiated by peers, both in two time points. The qualitative part of the study presented the results of the assessment of interaction quality, and the quality of responsiveness to interaction initiated by peers, also in two time points. The results confirmed the hypothesis of the research; the effectiveness of using Social Stories as a treatment for social interaction skills in participant was confirmed, implying the need for implementation of Social Stories combined with video modelling in the further educational goals of the participant, as well as the need for further research in order to ensure evidence-based practice in the use of Social Stories in a population of children with high-functioning autism.
\end{abstract}

Keywords: autism spectrum disorder, high-functioning autism, social interaction, Social Stories, Video Modelling 